\title{
Использование биоцидных препаратов при поении цыплят-бройлеров для повышения продуктивных показателей
}

\begin{abstract}
Бурова Д.А., младший научный сотрудник, соискатель отдела технологии производства продуктов птицеводства ФГБНУ Федеральный научный центр «Всероссийский научно-исследовательский и технологический институт птицеводства» Российской академии наук (ФНЦ «ВНИТИП» РАН)
\end{abstract}

Аннотация. Прибодятся зоотехнические результаты быращ, Вания цыплят-бройлеров (4 группы по 35 голов при клеточном содержании) при использовании различных биоцидных препаратов $\boldsymbol{b}$ питьевой воде. Контрольную группу поили бодопрободной бодой без добабок; опытным группам 2 и 3 в боду добавляли средство «АНОЛИТ АНК СУПЕР» В концентрациях нейтрального анолита 0,25 и 10,0\% соответственно; опытной группе 4 б боду добавляли препарат «DUTRION». Установлено, что б группе 3 средняя живая масса была быше б сравнении с контролем на 1,83\%, ее среднесуточный прирост - на 1,87\%, сохранность поголовья на 6\%, индекс эфрфективности - на 35 ед. при снижении затрат корма на 2,47\%. В группе 4 средняя живая масса была быше в сравнении с контролем лишь на 0,86\%, ее среднесуточный прирост - на 0,75\%, сохранность поголовья - на 3\%, индекс эфрфективности - на 21 ед. при снижении затрат корма на 2,47\%. Сделан Вывод, чтоо наилучшие зоотехнические показатели были достигнуты при поении цыплят 10\% раствором «АНОЛИТ АНК СУПЕР».

Ключебые слова: цыплята-бройлеры, продуктибность, обеззаражибание, микрофлора.

Введение. Уровень производства мяса птицы в последние годы предопределяет высокие темпы развития его водоснабжения. На птицеводческих предприятиях воду расходуют в значительных количествах на производственные (технические) и питьевые нужды [1-3].

Качество воды, которая используется для поения животных и птицы, не всегда в полной мере отвечает санитарногигиеническим требованиям. Статистика по заболеваниям на птицеводческих площадках России приводит следующие данные: около 68\% регистрируемых диагнозов приходится на заболевания бактериальной этиологии. Некоторые из них являются общими для человека и животного, что, в свою очередь, в нынешних условиях жесткой конкуренции на внутреннем продовольственном рынке России, ставит под удар не только здоровье птицы, качество тушки, материальное благополучие птицефабрики, но и здоровье конечного потребителя [4]. В современных условиях ведения животноводства и птицеводства не представ- ляется возможным оценить масштабы заболеваемости и гибели животных и птицы, вызываемых условно-патогенной микрофлорой, так как эта группа инфекционных заболеваний не подлежит обязательной регистрации [5].

Вода - один из важных факторов, оказывающих влияние на состояние здоровья и продуктивность птицы. Общеизвестно, что вода является важнейшей составной частью внешней среды, без которой невозможны поддержание здоровья и получение высокой продуктивности. Роль питье- 
вой воды в организме птицы велика. Она влияет фактически на все физиологические функции [6].

Количество воды в организме птиц, участвующей в обмене веществ, в определенной степени является постоянной величиной. Установлено, что недостаток воды может возникнуть при нерегулярном приеме воды, повышенной отдаче и нарушении водной резорбции в почках. Снижение живой массы у птицы за счет потери воды может составлять от $5 \%$ до 15\%. Также установлено, что уменьшение приема воды приводит к нарушениям осмотического давления в плазме клеток, вследствие чего происходит их морфологическая дегенерация. Рост задерживается, снижается прием корма. В результате смертность в первую неделю жизни высокая [7].

Следует обратить внимание на то, что продуктивность птицы зависит от множества факторов: условий содержания, генетического потенциала, кормовой базы, ветеринарного обеспечения. Но очень важный и часто неучтенный фактор - наличие качественной питьевой воды.

Современные препараты зарубежного производства позволяют специалистам проводить санацию воды с дальнейшей выпойкой ее птице, хотя в настоящее время они

Таблица 1. Схема опыта

\begin{tabular}{ccc} 
Группа & Кол-во цыплят & Особенности поения \\
\hline $1($ (к) & 35 & Водопроводная вода. \\
\hline 2 & 35 & $0,25 \%$ раствор среАства «АНОЛИТ AHК СУПЕР \\
\hline 3 & 35 & 10\% раствор средства «АНОЛИТ АНК СУПЕР» \\
\hline 4 & 35 & Препарат «DUTRION» - по рекомендации \\
фирмы-производителя
\end{tabular}

являются дорогостоящими, а следовательно, способствуют значительному повышению себестоимости готовой продукции.

Целью наших исследований было сравнительное изучение эффективности использования в поении цыплят-бройлеров в период выращивания препаратов «DUTRION» и «АНОЛИТ АНК СУПЕР»

\section{материал и методика}

исследований. Опыт был проведен в отделе технологии производства продукции птицеводства ФНЦ «ВНИТИП» РАН и в виварии СГЦ «Загорское ЭПХ».

Было сформировано 4 группы цыплят-аналогов по 35 голов в каж- дой. Птицу выращивали в клеточных батареях R-15. Цыплята контрольной группы 1 получали обычную водопроводную воду. В опытной группе 2 добавлялось средство «АНОЛИТ АНК СУПЕР» для получения 0,25\% раствора нейтрального анолита. В опытной группе 3 цыплята получали 10\% раствор нейтрального анолита. В питьевую воду опытной группы 4 добавлялся препарат «DUTRION» - по рекомендации фирмыпроизводителя (сначала готовился маточный раствор - 1 таблетка растворялась в 1 л воды, а далее 0,75 мл раствора на 1 л воды). Схема опыта представлена в табл. 1 .

Препарат «DUTRION» - это диок-

\begin{tabular}{|c|c|c|c|c|}
\hline \multirow[t]{2}{*}{ Показатель } & \multicolumn{4}{|c|}{ Группа } \\
\hline & 1 (к) & $2(0,25 \% p-p)$ & $3(10 \% p-p)$ & 4 «DUTRION» \\
\hline \multicolumn{5}{|l|}{ Средняя живая } \\
\hline масса в 36 дней, г & $1952 \pm 33,5$ & $1957 \pm 35,0$ & $2002 \pm 31,0$ & $1962 \pm 34,2$ \\
\hline в т.ч. петушки & $2034 \pm 56,2$ & $2048 \pm 52,9$ & $2056 \pm 49,5$ & $20581 \pm 55,0$ \\
\hline курочки & $1899 \pm 35,6$ & $1860 \pm 27,4$ & $1949 \pm 30,5$ & $1915 \pm 39,2$ \\
\hline ср. арифм. & 1966 & 1954 & 2002 & 1983 \\
\hline \multicolumn{5}{|l|}{$\begin{array}{l}\text { Среднесуточный } \\
\text { прирост живой }\end{array}$} \\
\hline массы, г & 53,5 & 53,2 & 54,5 & 53,9 \\
\hline \multicolumn{5}{|l|}{$\begin{array}{c}\text { Затраты корма на } 1 \text { кг } \\
\text { прироста живой }\end{array}$} \\
\hline массы, кг & 1,62 & 1,61 & 1,58 & 1,58 \\
\hline $\begin{array}{l}\text { Сохранность } \\
\text { поголовья, \% }\end{array}$ & 94 & 94 & 100 & 97 \\
\hline $\begin{array}{c}\text { EPEF (индекс } \\
\text { эффективности) }\end{array}$ & 317 & 317 & 352 & 338 \\
\hline
\end{tabular}


сид хлора, селективный окислитель, очень сильный биоцид (убивает все бактерии, вирусы, споры, грибки, плесень, водоросли и т.п.).

Средство «АНОЛИТ АНК СУПЕР» получали путем электролиза водопроводной воды в проточной установке СТЭЛ АНК СУПЕР-100. «АНОЛИТ АНК СУПЕР» является самым совершенным продуктом этого типа, поскольку содержание балластных ионов (хлорида натрия) в нем намного меньше концентрации оксидантов или совсем отсутствует. Концентрация оксидантов в пересчете на активный хлор составляет не менее 0,5 г/л (0,05\%) при общем содержании растворенных веществ (минерализации) не более 0,9 г/л и $\mathrm{pH}$ раствора 5,06,5. Метастабильная смесь оксидантов представлена хлоркислородными и гидропероксидными соединениями: хлорноватистая кислота (50-95\%), диоксид хлора (1-7\%), пероксид водорода (3-8\%), другие пероксидные и супероксидные соединения (1-5\%) [8].

\section{Результаты исследований и}

их обсуждение. Зоотехнические показатели выращивания цыплятбройлеров представлены в табл. 2.

Лучшей по средней живой массе и ее среднесуточному приросту оказалась опытная группа 3. Сред- няя живая масса цыплят в ней была выше, чем у сверстников контрольной группы и опытных групп 2 и 4, на 1,$83 ; 2,46$ и 0,96\% соответственно. Среднесуточный прирост живой массы в этой группе был выше показателей контрольной группы 1 и опытных групп 2 и 4 на 1,87; 2,44 и 1,11\% соответственно.

Наименьшие затраты корма на 1 кг прироста живой массы были в опытных группах 3 и 4 и составили 1,58 кг, что на 2,47 и 1,86\% ниже по сравнению с контролем и опытной группой 2 соответственно. Было также установлено, что сохранность поголовья зависела от концентрации нейтрального анолита в питьевой воде. В контрольной и опытной группе 2 данный показатель составил 94,0\%, что было ниже по сравнению с опытной группой 3 на 6\%. Использование в питьевой воде препарата «DUTRION» повысило сохранность птицы на 3\% по сравнению с контролем.

Заключение. Использование 10\% раствора «АНОЛИТ АНК СУПЕР» для поения цыплят способствовало повышению средней живой массы на 1,83\%, ее среднесуточного прироста - на 1,87\%, сохранности поголовья - на 6\%, индекса эффективности - на 35 ед. при снижении затрат корма на 2,47\% в сравнении с контролем, в котором цыплят поили обычной водопроводной водой.

Препарат «DUTRION», в свою очередь, способствовал повышению средней живой массы лишь на $0,86 \%$, ее среднесуточного прироста - на 0,75\%, сохранности поголовья - на 3\%, индекса эфффективности - на 21 ед. при снижении затрат корма на 2,47\%.

Таким образом, очевидно, что наилучшие зоотехнические показатели были достигнуты при выпойке цыплят 10\% раствором «АНОЛИТ АНК СУПЕР».

\section{Литература}

1. Колычев Н.М., Плешакова В.И., Колотило А.Н., Метлева А.С., Лещева Н.А. Микробиоценоз воды, используемой на животноводческих предприятиях Омского Прииртышья // Ветеринария. - 2015 . - №8. - C. 40-44.

2. Банников В. Аспекты гигиены воды в сельскохозяйственной отрасли // БИО. - 2006- №7. - C. 23-24.

3. Брылин А.П., Листкова Н.А. Гигиена снабжения питьевой водой // Ветеринария. - 2006. - №1 1. - С. 11 - 12.

4. Плешаков А.В. Вода - ключ к успеху в птицеводстве! // Ветеринария. - 2014. №9. - C. 40-43.

5. Горковенко Н.Е. Использование факторов персистенции бактерий в оценке микробиологического качества воды // Докл. РАСХН. - 2006. - №4. - С. 47-49. 6. Кавтарашвили А. Ш. Обмен воды и потребность в ней птицы // Птицеводство. - 2012. - №7. - С. 13-17. 


\section{7. Дмитриева М. Е. Ветеринарное бла-}

гополучие - залог рентабельной рабо-

ты птицеводческого предприятия //

Птица и птицепродукты. - 2014 . - № 1 . -

\section{23-25.}

8. Бахир В. М. Электрохимическая акти-

вация: изобретения, техника, техноло-

гия. - Москва: Вива-Стар, 2014. - 511 с.

\section{Для контакта с автором:}

Бурова Дарья Александровна

E-mail: daryaburowa@yandex.ru

\title{
The Efficiency of Different Biocide Preparations in Drinking Water for Broilers
}

\author{
Burova D.A.
}

Federal Scientific Center "All-Russian Research and Technological Institute of Poultry" of Russian Academy of Sciences

Summary: The growth efficiency in broiler chicks (4 treatments, 35 cage-housed birds per treatment) was studied with the use of different biocide preparations in their drinking water. Water for control treatment 1 did not contain biocides; water for experimental treatments 2 and 3 was supplemented with preparation "Anolyte ANK Super" (concentrations of neutral anolyte 0.25 and $10.0 \%$, respectively); water for experimental treatment 4 was supplemented with preparation "DUTRION". It was found that average live bodyweight in treatment 3 was higher in compare to control by $1.83 \%$, average daily weight gains by $1.87 \%$, mortality lower by 6.0\%, European Production Efficiency Factor higher by 35 points, feed conversion ratio better by $2.47 \%$. In treatment 4 these improvements in compare to control were $0.86 \%$, 0.75\%, 3.0\%, 21 points, and 2.47\%, respectively. The conclusion was made that the best growth efficiency was achieved with 10\% solution of "Anolyte ANK Super".

Key words: broiler chicks, productive performance, disinfection, microflora.

\section{График проведения курсов повышения квалификации специалистов} птицеводческих организаций в ФНЦ «ВНИТИП» РАН в 2020 г.

Инновации в племенной работе и воспроизводстве сельскохозяйственной TEMA CEMИНАРA

ДАТА ПРОВЕДЕНИЯ

птицы (для руководителей птицеводческих предприятий, зоотехников-селекционеров, ветврачей, бонитеров, начальников цехов ремонтного молодняка и родительских стад, специалистов по искусственному осеменению, преподавателей и аспирантов ВУЗов)

Актуальные проблемы и пути их решения в современной практике инкубации яиц сельскохозяйственной птицы (для зоотехников, ветврачей, заведующих и механиков цехов инкубации)

Инновационные ресурсосберегающие технологии производства яиц и мяса птицы (для руководителей, технологов, зоотехников, ветврачей, инженеров, начальников цехов и бригадиров птицеводческих предприятий и преподавателей ВУЗов)

Современные технологии в кормопроизводстве, кормлении высокопродуктивных кроссов птицы, контроль безопасности и качества комбикормов, премиксов, биологически активных добавок (для технологов птицехозяйств и комбикормовых предприятий, ветврачей, заведующих зоо- и ветлабораториями, зоотехников по кормам, преподавателей ВУЗов)

Комплексные решения повышения доходности птицеводческих предприятий, как вектор развития потенциала отрасли (для руководителей предприятий, руководителей финансово-экономических

$17-21$ февраля $23-27$ ноя яя

$16-20$ м а т а 19 - 23 октября

13 - 17 апреля 21 - 25 сентября

14 - 18 сентября

Дополнительную

информацию можно

Курсы повышения квалификации специалистов птицеводческих организаций будут проводиться совместно со специалистами Росптицесоюза.

По окончании курсов выдается удостоверение о повышении квалификации государственного образца.

Во время проведения курсов повышения квалификации продается новая научная литература по птицеводству. 